\title{
Restaurant wastewater treatment with a two-chamber septic tank and a sequencing batch reactor
}

\author{
Novirina Hendrasarie ${ }^{*}$, MYC Nugraha, and Kabul Fadilah \\ Department of Environmental Engineering, University of Pembangunan Nasional "Veteran” Jawa Timur, Indonesia.
}

\begin{abstract}
Restaurant wastewater in Indonesia comprises a variety of organic components that are difficult to degrade, such as COD, BOD, TSS, and oils and fats. Although grease traps are usually used to collect restaurant wastewater, the effluent still exceeds the applicable standards. For this reason, the combined technology of a two-chamber septic tank (ST) and a sequencing batch reactor (SBR) was chosen for this investigation. Both are biological treatment methods that involve an anaerobic and aerobic phase. This reactor will operate with a continuous influent flow that will be processed sequentially but discharged intermittently. The hydraulic retention time (HRT) of the ST-SBR was 12, 24, 36, and 48 hours, at aeration rates of 7 and $14 \mathrm{~L} / \mathrm{min}$, respectively. The results showed that introducing a Septic Tank increased the percentage of organic content removed and shortened the optimal HRT, resulting in a 24-hour optimal HRT and a $14 \mathrm{~L} / \mathrm{min}$ aeration rate. With an average efficiency of $86.72 \%$ to $98.63 \%$ in removing organic components.
\end{abstract}

Keywords: Wastewater, SBR, Biological Treatment Methods

\section{Introduction}

$\mathrm{COD}, \mathrm{BOD}_{5}$, TSS, oil, and grease levels in water bodies rise as a result of untreated restaurant wastewater $[1,2]$. In the context of these conditions, a grease trap is an effective treatment for improving the quality of wastewater in restaurants. However, only using grease traps for wastewater treatment does not meet the needed quality criteria. According to research conducted by [3], using grease traps as a solution to lower the concentration of oil and fat in wastewater has been proven, but it is insufficient to reduce the concentration of organic matter to meet the standard. The biological treatment technique Sequencing Batch Reactor is one technology that may be used to improve the quality of wastewater that has not yet reached the quality level from grease trap processed wastewater (SBR) [4].

The Sequencing Batch Reactor (SBR) is an activated sludge process variation that combines all treatment operations in one tank, both aerobic and anaerobic processes [5, 6]. According to previous research, SBR can remove organic materials from residential wastewater in the form of COD at a rate of $73.49 \%$ and Total-N at a rate of $75 \%$ [7]. The Sequencing Batch Reactor-Continuous Flow system, with an aeration intensity of 9.74 hours and a retention period of 9 hours, was then used in the study to remove organic matter from residential waste and able to reduce $75 \%$ Total-N as well as 95\% COD [8].
The septic tank is a regularly used individual household wastewater treatment technique. A septic tank is an impermeable room with a compartment that is used to accommodate/treat wastewater at a very slow flow rate to allow for the deposition of suspended solids and the decomposition of organic compounds by anaerobic bacteria $[9,10]$. This process occurs naturally, separating solids from liquids in the form of a more stable mud (supernatant). In addition, biogas is also produced as a result from anaerobic process [11]. The treated liquid will be discharged as effluent from the septic tank, and the gas produced will be vented through the ventilation pipe. Meanwhile, the mature (stable) sludge will sink to the tank's bottom and will need to be drained regularly [12].

According to several of the studies mentioned above, even if we only use a septic tank, the organic content still exceeds the requirement when discharged into water bodies [13]. Restaurant wastewater has a significant organic nitrogen content, and standard SBR can only reduce home wastewater by $75 \%$ [7]. Starting with this, the Septic Tank, which is often used in home wastewater treatment, was combined with SBR, a waste treatment that combines many processes in one reactor. In this study, the goal of combining these two reactors is to achieve optimal organic content reduction and minimize hydraulic retention time.

\footnotetext{
* Corresponding author : novirina@upnjatim.ac.id
} 


\section{Research Methods}

\subsection{Properties of Wastewater}

Samples of wastewater were collected from the Restaurant's wastewater treatment inlet. COD, TSS, total Nitrogen, and total phosphate as $\mathrm{P}$ are the first characteristics of restaurant wastewater, with values ranging from 2237,2 to $3551,02 \mathrm{mg} / \mathrm{L}$, $1010-1460 \mathrm{mg} / \mathrm{L}, 104,33-136,2 \mathrm{mg} / \mathrm{L}$, and 20,04-29,2 mg/L, respectively.

\subsection{The Process of Sequencing Batch Reactor}

Two types of test reactors were employed in this investigation. The first was a septic tank-SBR reactor hybrid that allowed wastewater to be treated sequentially and released intermittently. The SBR reactor with a septic tank was the first, while the SBR reactor without a septic tank was the second. The combined Septic Tank and SBR ( $\varnothing \mathrm{xH}: 22 \mathrm{~cm}$ x $20 \mathrm{~cm})$ reactor was made up of one container with a maximum capacity of 120 liters, one discharge control tank with a maximum capacity of 70 liters, four anaerobic reactor tanks (pxLxH: $48 \times 30 \times 20 \mathrm{~cm}$ ) with a maximum capacity of 10 liters, and eight SBR tanks with a maximum capacity of 5 liters filled with a bubble aerator. A valve in the discharge control tank, which was 70 liters in size, drew the effluent to the reactor anaerobes. The treated water could also be drained to the SBR reactor for reprocessing through a valve in the anaerobic reactor tank. Within the discharge control tank, there was an overflow hole that served to stabilize the volume so that it could be maintained. Overflowing water will be pumped back into the reservoir. The second reactor had a capacity of 5 liters and was an SBR reactor without a septic tank.

The SBR reactor will have a 5-liter processing capacity. There was active sludge inside the reactor, which amounted to up to $1 / 3$ of the reactor's capacity and had been seeded and acclimatized. Inside the SBR reactor, a bubble aerator with different aeration rates, specifically $7 \mathrm{~L} /$ minute, and $14 \mathrm{~L} /$ minute, functions similarly to an aerobic reaction process. A schematic of the reactor is shown in Figure 1.

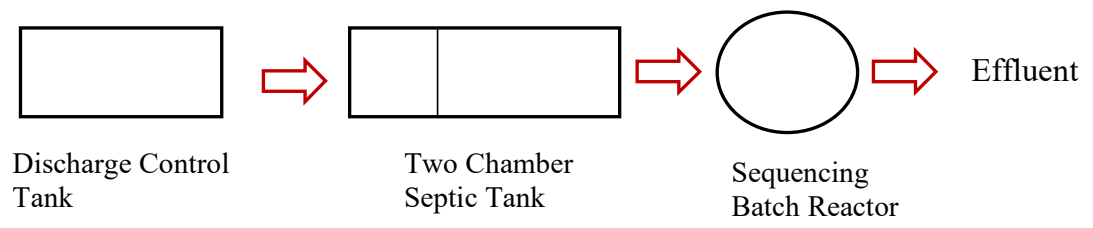

Fig. 1. Schematic of a Septic Tank and a Sequencing Batch Reactor

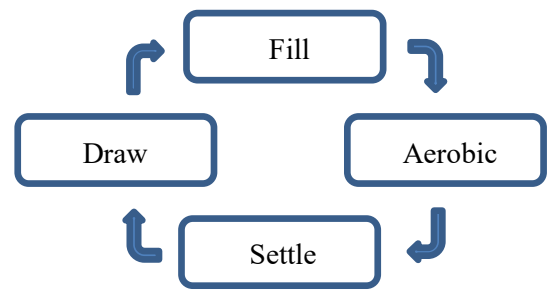

Fig. 2. Mechanism of Sequencing Batch Reactor in each phase

\subsection{Seeding and Acclimatization}

Seeding followed by acclimation is required to develop degrading the bacteria from organic liquid waste. Restaurant wastewater was used by the bacteria as a nutrient for supporting the viability, with a composition of $\mathrm{N}: \mathrm{P}: \mathrm{K}=1: 1: 1$ and glucose, the seeding process is carried out to grow bacteria. MLSS (Mixed Liquor Suspended Solids) was measured at $2000-5000 \mathrm{mg} / \mathrm{L}$. Tchobanoglous et al. [14] then began the acclimatization process. Acclimatization was placed as the wastewater content was gradually increased, and the COD concentration was reduced by $50 \%$ in the experiments.

\subsection{Research Variables}

The research continued after seeding and acclimation by changing the discharge in each reactor as well as the airflow rate for aeration. The aeration rates employed are 7 and 14 liters per minute, and their performance in the SBR reactor will be compared. $\mathrm{pH}, \mathrm{COD}$, TSS, Total Nitrogen, and $\mathrm{PO}_{4}$ are the most common parameters in restaurant wastewater that exceed the quality standard. The hydraulic retention period, which was varied at $12,24,36$, and 48 hours. Table 1 shows the distribution of time variables in this study in detail. 
Table 1. The distribution of time variables in this study is in detail.

\begin{tabular}{|c|c|c|c|c|c|}
\hline \multirow{2}{*}{ Reactor } & \multirow{2}{*}{ Phase } & $\mathbf{1 2} \mathbf{~ h r}$ & $\mathbf{2 4} \mathbf{~ h r}$ & $\mathbf{3 6} \mathbf{~ h r}$ & $\mathbf{4 8 ~ h r}$ \\
\cline { 3 - 6 } & & 360 minute & 720 minute & 1080 minute & 1440 minute \\
\hline Septic Tank & Fill & 10 minute & 10 minute & 10 minute & 10 minute \\
\hline \multirow{3}{*}{ SBR } & Serobic React & 270 minute & 540 minute & 810 minute & 1080 minute \\
\cline { 2 - 6 } & Settle & 50 minute & 100 minute & 150 minute & 200 minute \\
\cline { 2 - 6 } & Decant & 10 minute & 10 minute & 10 minute & 10 minute \\
\cline { 2 - 6 } & Idle & 20 minute & 60 minute & 100 minute & 140 minute \\
\cline { 2 - 6 } & & & & &
\end{tabular}

\section{Results and Discussion}

\subsection{The Septic Tank's ability to decrease the organic content of restaurant wastewater.}

The hydraulic retention period, which was varied at 12 , 24,36 , and 48 hours, was used to determine the effectiveness of the Septic Tank's ability to reduce the organic content of restaurant wastewater. The hydraulic retention period determines how effective the Septic Tank is at reducing the organic content of restaurant wastewater. In the graph in Figure 2, at the zero hour HRT position, there is an Equalization tank that works to stabilize flow fluctuations such that when entering the Septic Tank, the flow conditions are relatively laminar.

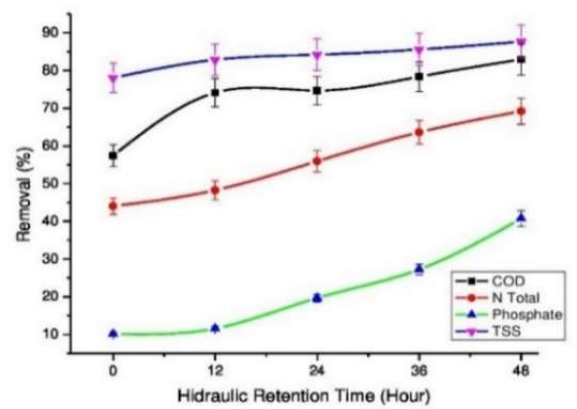

Fig. 3. Organic Content Reduction in Septic Tanks as a Function of Hydraulic Retention Time

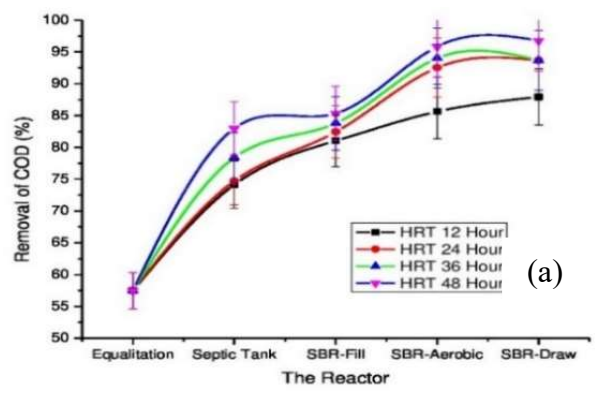

Figure 3 shows the efficiency of the decrease in each organic content, including COD, Total Nitrogen, Phosphate, and TSS, in the Septic Tank reactor, which indicate a sharp increase in line with the increase in Hydraulic Retention Time. At 48 hours HRT, the COD reduction was the highest, at $82.99 \%$. This indicates that the bacteria in the anaerobic reactor can thrive. This reduction occurs throughout the steps of hydrolysis and fermentation, acetogenesis, and methanogenesis when organic matter is transformed into biogas or methane and carbon dioxide. The three steps will generate hydrogen gas, carbon dioxide, and methane [15].

\subsection{The effectiveness of phase in the SBR cycle in reducing organic parameters}

The influence of phase changes in SBR on the decrease in organic content, particularly COD, Total Nitrogen, phosphate, and TSS, was investigated using HRT in this work.

\subsubsection{Removal of $C O D$}

The stabilization phase (idle) and aerobic reaction time, in addition to microorganism, aeration, and decomposition factors, influence COD removal. The longer the HRT, the longer the stabilization and aerobic reaction [16]. However, COD began to be removed from the filling stage because the wastewater at this point contained high amount of organic matter.

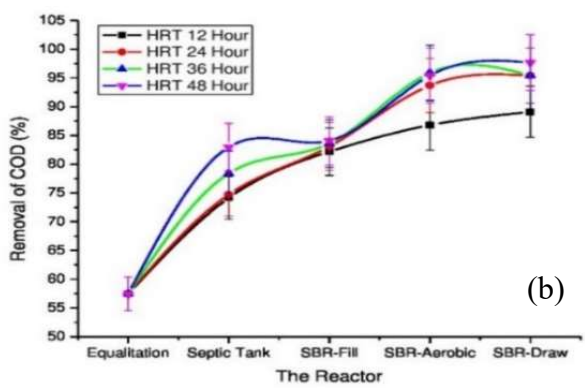

Fig. 4. COD Reduction Efficiency in an Equalization Tank-Septic Tank-Sequencing Batch Reactor Using Aeration Rate, (a) $7 \mathrm{~L} / \mathrm{min}$ and (b) $14 \mathrm{~L} / \mathrm{min}$ 
To reduce $\mathrm{COD}$, the difference in aeration rate enhance the decrease in total $\mathrm{N}$ in the aerobic and draw phases, as shown in Figure 4. COD removal efficiency is steady at around $75 \%$ of the 12 -hour to 48 -hour HRT, reaching a maximum of $95 \%$ for the remaining operations period on average. Organic matter is consumed for a minimum of 360 minutes in a septic tank, followed by an aeration phase during which the DO concentration was around $0.82-2.67 \mathrm{mg} \mathrm{O}_{2} \mathrm{~L}^{-1}$, according to COD measurements. This shows that anaerobic and aerobic reactions can both help to reduce Total $\mathrm{N}$ levels in wastewater. Figure 4 shows total

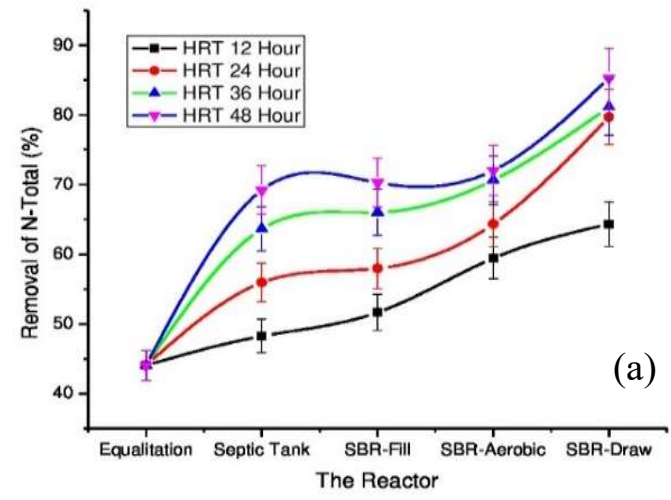

nitrogen degradation in SBRs based on hydraulic retention time and for each phase.

\subsubsection{Removal of Total Nitrogen}

Total nitrogen concentrations in the initial wastewater sample range between 100 and $150 \mathrm{mg} / \mathrm{L}$. Increasing the aeration rate from 7 to $14 \mathrm{~L} / \mathrm{min}$ during the aerobic and draw phases resulted in a significant reduction in total Nitrogen.

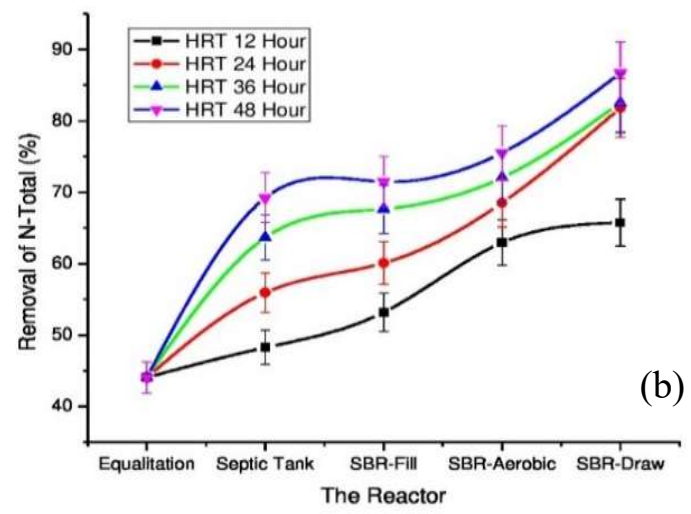

Fig. 5. Total Nitrogen Reduction Efficiency in an Equalization Tank-Septic Tank-Sequencing Batch Reactor at Aeration Rates of (a) $7 \mathrm{~L} / \mathrm{min}$ and (b) $14 \mathrm{~L} / \mathrm{min}$

At 48 hours HRT, the anaerobic reactor phase had the greatest decrease in Total $\mathrm{N}$, with a reduction of $69.23 \%$. Because the contact time between wastewater and activated sludge is increasing longer, the value of the Total $\mathrm{N}$ removal parameter is better when the hydraulic retention time (HRT) is longer in this study. In addition, the aerobic reaction time increased with the amount of time the HRT was used. According to [17], both the anaerobic and aerobic reactions were able to reduce the total nitrogen concentration in domestic wastewater. This could be attributed to nitrification and denitrification processes which occur in aerobic anaerobic reactions, lowering total $\mathrm{N}$.

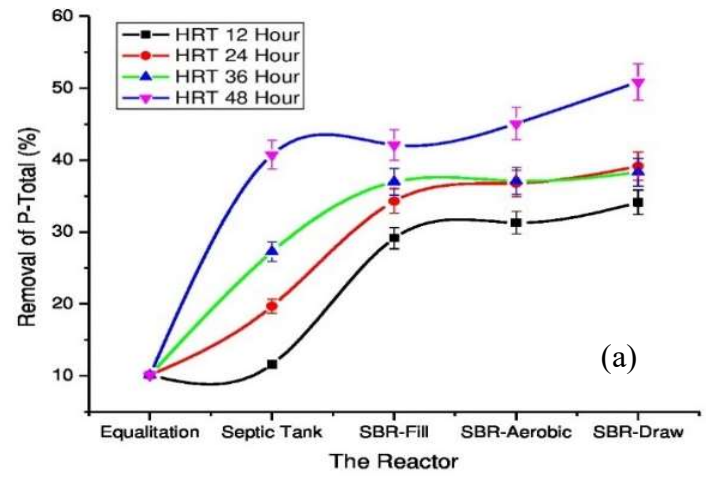

\subsubsection{Removal of Total Phosphate}

In the presence of anaerobic-aerobic conditions, phosphate compounds are removed. Phosphate will be released under anaerobic conditions, while phosphate compounds will be absorbed again under aerobic conditions [18]. Bacteria obtain energy from the decomposition of polyphosphates and release Pi under anaerobic conditions. Polyphosphate collecting organisms (PAOs) recover polyphosphate by absorbing phosphate from wastewater under aerobic conditions. Sludge containing intracellular polyphosphate will be used to dispose of the phosphate.

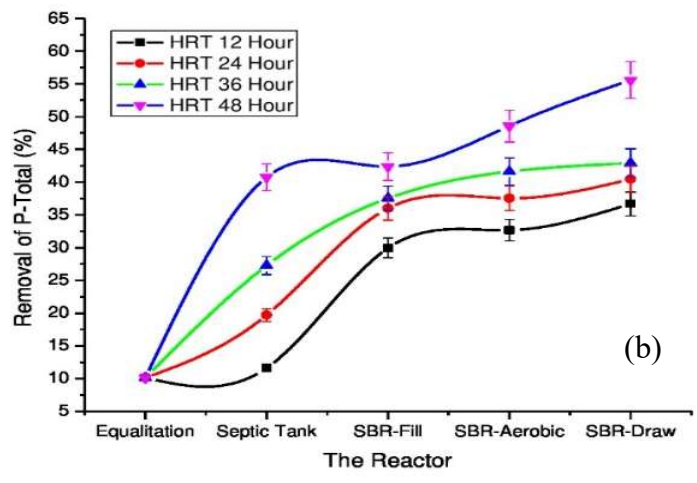

Fig. 6. Total Phosphate Reduction Efficiency in an Equalization Tank-Septic Tank-Sequencing Batch Reactor At Aeration Rates of (a) $7 \mathrm{~L} / \mathrm{min}$ and (b) $14 \mathrm{~L} / \mathrm{min}$ 
The septic tank produced the maximal $\mathrm{PO}_{4}$ removal, up to $40.75 \%$ at 48 hours HRT. Because the release of phosphate usually occurs after denitrification, the efficiency of phosphate compound removal increased as the retention time (HRT) increases [8].

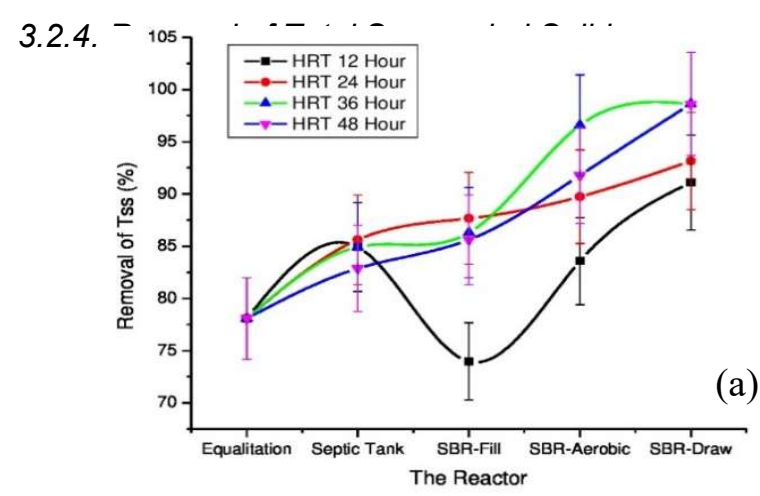

The settling stage is one of the steps that take place in the SBR reactor. This stage aims to remove Total Suspended Solid (TSS), and it can do so through the sedimentation process, as well as the sedimentation treatment unit. The following is the TSS removal effectiveness for each HRT generated through the SBR operating method described in Figure 7.

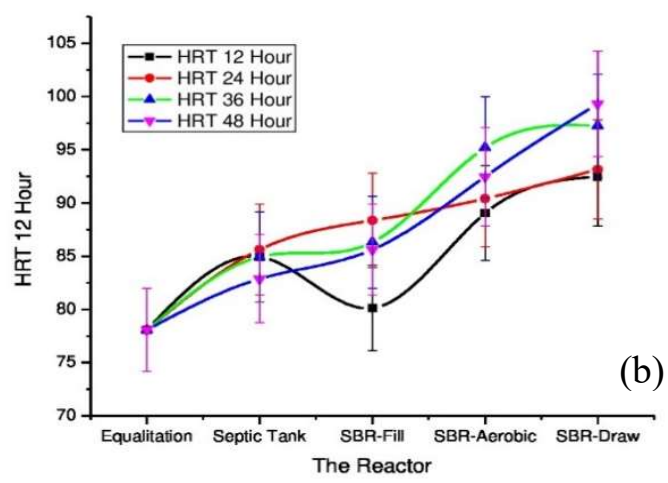

Fig. 7. Total Suspended Solid (TSS) Reduction Efficiency in an Equalization Tank-Septic Tank-Sequencing Batch Reactor At Aeration Rates of (a) $7 \mathrm{~L} / \mathrm{min}$ and (b) $14 \mathrm{~L} / \mathrm{min}$

TSS reduced by $82.88 \%$ in the septic tank after 48 hours of HRT and then continued in the SBR until it reached a maximum of $87.67 \%$. This large reduction in concentration in the SBR-CF reactor was aided by the design of a simple septic tank with two rooms and a low flow rate based on the HRT used, so the longer the HRT is used, the lower the concentration becomes. The smaller the output, the more laminar the flow, and the more suspended solids can be trapped in the septic tank's space.

\subsection{Dissolved Oxygen and $\mathrm{pH}$ Characteristics}

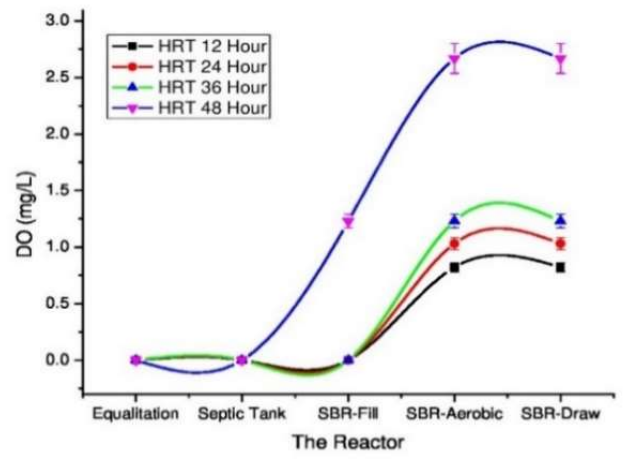

Fig. 8. DO Characteristics in a Batch Reactor with an Equalization Tank, a Septic Tank, and a Sequencing Batch Reactor
The DO concentration in the SBR is affected by changes in the aeration rate. The anaerobic reactor stage's DO concentration was successfully conditioned to $0.0 \mathrm{mg} / \mathrm{l}$, indicating that it is anaerobic (Figure 7). Denitrification is considered anaerobic when the DO value is less than $0.5 \mathrm{mg} / 1$ [14]. Where this requirement has a significant impact on the decrease in the Total $\mathrm{N}$ parameter, allowing the denitrification process to proceed as efficiently as possible. Because the activated sludge in SBR is aerobic microbe biomass, where the higher the activity, the more oxygen consumed, DO levels in the aerobic phase and fill phase are only $3 \mathrm{mg} / 1$ [7].

The $\mathrm{pH}$ of the initial wastewater was in the range of 5 in this investigation under alkaline water. As the Septic Tank process progressed, the $\mathrm{pH}$ continued to rise, approaching neutral (6.5). During the aerobic phase of the SBR process, the $\mathrm{pH}$ increased, but towards the end of the draw phase, it was neutral at 6.5-7.0. Figure 8 illustrates the point.

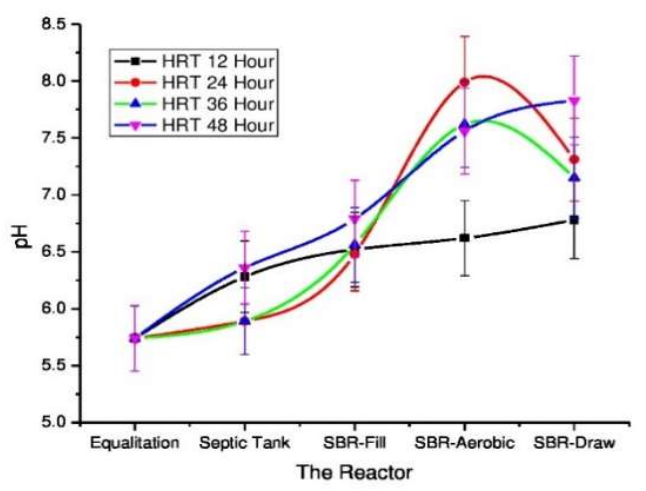

Fig. 9. $\mathrm{pH}$ Characteristics in the Equalization Tank, Septic Tank, and Sequencing Batch Reactor Processes 
It may be said that it is capable of treating restaurant wastewater based on the efficiency of the Equalization Tank, a Septic Tank, and a Sequencing Batch Reactor. The DO and $\mathrm{pH}$ valus at the time of processing show that the biological wastewater treatment process, as well as the organic content of restaurant wastewater, are in great condition.

\section{Conclusion}

The effectiveness of the Septic Tank-Sequencing Batch Reactor to treat restaurant wastewater in the best phase obtained in the anaerobic phase in the Septic Tank and the aerobic phase in the Sequencing Batch Reactor. At the optimum condition of 24-hour HRT with an aeration rate of $14 \mathrm{~L} /$ minute, the ability to remove organic content on the COD parameters was $95.40 \%$. The removal of total nitrogen, phosphorus, and total suspended solids were $81.82 \%, 40.48 \%$, and $93.18 \%$, respectively. Hydraulic retention time (HRT) has an effect on lowering pollutant parameters' concentrations, with 24hour HRT being the optimum HRT for reducing organic matter content in wastewater. The aeration rate has an effect on reducing pollutant parameters' concentrations, with $14 \mathrm{~L} / \mathrm{min}$ being the best aeration rate for reducing the organic matter content in restaurant wastewater.

The authors gratefully acknowledge the financial support for this work by the Ministry of Higher Education Indonesia, 2021.

\section{References}

1. Z. V. P. Murthy, C. Nancy, and A. Kant, Sep. Sci. Technol., 42, 819-833 (2007).

2. S. Zulaikha, W. J. Lau, A. F. Ismail, and J. Jaafar, J. Water Process Eng. 2, 58-62 (2014).

3. N. Hendrasarie and S. H. Maria, South African J. Chem. Eng. 37, 196-205 (2021).

4. I. I. Yadaturrahmah and N. Hendrasarie, Envirotek J. Ilm. Tek. Lingkung. 13, 7-13 (2021).

5. U. Showkat and I. A. Najar, Appl. Water Sci. 9, 110 (2019).

6. N. I. Said, Tekhnologi Pengolahan Air Limbah: Teori dan Aplikasi. (Erlangga, Yogyakarta, 2019).

7. N. Hendrasarie, F. I. Zarfandi, F. Rosariawari, and R. K. H. Putro, Addition of Fixed Bed Biofilm in Sequencing Batch Reactor to Remove CarbonNitrogen for Apartment Wastewater, in IOP Conference Series: Materials Science and Engineering, 1125, 12089 (2021).

8. D. Li, S. Zhang, S. Li, H. Zeng, and J. Zhang, Bioresour. Technol. 292, 122024 (2019).

9. G. Moussavi, F. Kazembeigi, and M. Farzadkia, Process Saf. Environ. Prot, 88, 47-52 (2010).

10. J. Diak, B. Örmeci, and K. J. Kennedy, Bioprocess Biosyst. Eng. 36, 417-424 (2013).

11. P. Chatterjee, M. M. Ghangrekar, and S. Rao, Waste. Bio. Valori. 10, 387-398 (2019).

12. C. Zamalloa, J. B. A. Arends, N. Boon, and W.
Verstraete, N. Biotechnol., 30, 573-580 (2013).

13. K. Gunes, CLEAN-Soil, Air, Water, 35, 571-575 (2007).

14. G. Tchobanoglous, F. L. Burton, and H. D. Stensel, Wastewater engineering treatment and reuse. (Boston, US: McGraw-Hill Higher Education, 2003).

15. W. Ariani, S. Sumiyati, and I. W. Wardhana, J. Tek. Lingkung. 3, 1-10 (2014).

16. S. M. A. Masoudi, A. Hedayati Moghaddam, J. Sargolzaei, A. Darroudi, and V. Zeynali, Environ. Prog. Sustain. Energy, 37, 1638-1646 (2018).

17. F. A. Sekarani and N. Hendrasarie, Reduction of Organic Parameters in Apartment Wastewater using Sequencing Batch Reactor by adding Activated Carbon Powder, in IOP Conference Series: Earth and Environmental Science. 506, 12026 (2020).

18. X. Huo, L. Yuan, Q. Wang, D. Luo, R. Wang, and Y. Nan, Environ. Eng. Sci. 38, 66-73 (2021). 